* Mestre em Direito Negocial pela Universidade Estadual de Londrina (UEL). Pós-graduada em Direito Empresarial pela Universidade Estadual de Londrina (UEL). Bacharel em Direito pela Universidade Estadual de Maringá (UEM). Advogada no Escritório Medina \& Guimarães Advogados.

** Graduado em Direito pela Universidade Estadual de Londrina (1980), mestrado em Direito das Relações Sociais pela Universidade Estadual de Londrina (1985) e doutorado em Direito pela Pontifícia Universidade Católica de São Paulo (1997). Atualmente é professor associado da Universidade Estadual de Londrina.

\section{Fundamentos Principiológicos dos Negócios Jurídicos Processuais Previstos no Art. 190 do CPC/2015}

\author{
Fundamental Principles of Business \\ Legal Procedure Pursuant To Civil \\ Procedural Code, Art. 190
}

\section{Nida Saleh Hatoum* Luiz Fernando Bellinetti**}

Como citar: HATOUM, Nida Saleh. BELLINETTI, Luiz Fernando. Fundamentos principiológicos dos negócios jurídicos processuais previstos no art. 190 do CPC/2015. Revista do Direito Público, Londrina, v. 12, n. 3, p.242-278, dez. 2017. DOI: 10.5433/1980-511X2017v12n3p242. ISSN: 1980-511X.

Resumo: O art. 190 do CPC/2015 se apresenta como uma inovação, na medida em que autoriza que as partes celebrem negócios jurídicos processuais atípicos. A intenção do legislador, ao que parece, foi prestigiar o princípio do respeito ao autorregramento da vontade no processo enquanto desdobramento do princípio da liberdade, e também o princípio da cooperação, estatuído no art. $6 .^{\circ}$ do Novo Código e que se apresenta como norma fundamental do processo civil. Assim, o presente estudo se propõe à análise justamente destes dois princípios, que podem ser compreendidos como a base principiológica do instituto. $\mathrm{O}$ método adotado 
será o dedutivo.

Palavras-chave: Negócios jurídicos processuais. Fundamentos principiológicos. Novo Código de Processo Civil.

Abstract: The art. 190 of New Civil Procedure Code is an innovation, in that it authorizes the parties to enter into non-typical procedural legal transactions. The intention of the legislature, it seems, was to honor the principle of respect for self-preservation of the will in the process as unfolding of the principle of freedom, and also the principle of cooperation, laid down in art. $6 .^{\circ}$ of the New Code and which is presented as a fundamental norm of civil proceedings. Thus, the present study proposes to analyze precisely these two principles, which can be understood as the basis of the institute. The method adopted will be the deductive method.

Key words: Business legal procedure. Fundamental principles. New Civil Procedure Code. 


\section{INTRODUÇÃO}

O Novo Código de Processo Civil inquestionavelmente trouxe mudanças. Reorganizações estruturais relevantes consistentes na divisão entre parte geral e parte especial e na nova disposição dos livros, bem como alterações consideráveis atinentes à base principiológica adotada pelo novo diploma (arts. 1..$^{\circ}$ ao 12), à tutela provisória (arts. 294 ao 311) e ao processamento dos recursos (arts. 994 ao 1.044), dentre tantos outros pontos, indicam que estudos voltados especificamente a cada um desses temas serão imprescindíveis à compreensão de como se operacionalizará a nova legislação processual.

E é exatamente neste contexto que se encontra inserida aquela vista por muitos como uma das principais inovações contempladas pelo CPC/2015: a possibilidade de realização dos chamados negócios jurídicos processuais atípicos.

Embora diversos dispositivos abarquem as chamadas "convenções processuais" (entre eles os arts. 222, 357, 364, 380, 392 e 471), o art. 190 do Novo Código confere às partes a faculdade de modificar e regular o procedimento, adequando-o ao caso concreto, e de convencionar sobre situações jurídicas processuais, e o art. 191, ao seu turno, estabelece a possibilidade de fixação de um calendário processual.

Como é impossível que o ordenamento jurídico regule todas as situações submetidas ao crivo do Poder Judiciário, a possibilidade de celebração de acordos processuais, de acordo com as peculiaridades de cada lide, se propõe a prestigiar o princípio do respeito ao autorregramento da vontade e também o princípio da cooperação, estimulando a efetiva solução de conflitos.

Desse modo, este estudo se propõe ao exame dos fundamentos 
principiológicos dos negócios jurídicos processuais, quais sejam:

o princípio do respeito ao autorregramento da vontade no processo enquanto desdobramento do princípio da liberdade, e o princípio da cooperação, que se apresenta como norma fundamental do processo civil, porque inserto no art. $6 .^{\circ}$ do $\mathrm{CPC} / 2015$.

No primeiro capítulo, assim, serão analisados os negócios jurídicos processuais em seus aspectos mais elementares, tais como (i) seu conceito; (ii) a interpretação do já mencionado art. 190, caput, do CPC/2015 enquanto cláusula geral de negociação; (iii) seu objeto; e (iv) sua classificação. No segundo, então, será enfrentada a temática da base principiológica das convenções processuais, ou seja, (i) o princípio do respeito ao autorregramento da vontade no processo; e (ii) o princípio da cooperação.

\section{OS NEGÓCIOS JURÍDICOS PROCESSUAIS}

\section{Os negócios jurídicos processuais se apresentam como espécies} de atos jurídicos processuais em sentido amplo ${ }^{1}$, tendo em vista que a vontade é elemento nuclear do suporte fático, e, assim como os demais fenômenos processuais, podem ter seu conceito extraído daquele desenvolvido no campo da Teoria Geral do Direito², aqui considerados

1 Os atos processuais, como se sabe, são tratados especificamente no Livro IV do Código de Processo Civil de 2015, e se referem aparentemente justamente aos atos jurídicos processuais lato sensu, uma vez que abarcam os negócios jurídicos processuais, descritos no art. 190 do CPC/2015. No NCPC, então, os atos processuais são divididos em (i) atos da parte (arts. 200 a 202); (ii) atos do juiz (arts. 203 a 205); e (iii) atos do escrivão ou do chefe de secretaria (arts. 206 a 211). Cuida-se de classificação incompleta, entretanto, na medida em que outros sujeitos também podem praticar atos jurídicos no curso do processo, como os oficiais de justiça, depositários, peritos, testemunhas, leiloeiros, etc. (THEODORO JUNIOR, 2017, p. 480). Os atos processuais em sentido lato, então, podem ser compreendidos como os atos humanos necessariamente volitivos, consistindo em uma exteriorização de vontade consciente, que entram no mundo jurídico através da incidência de normas processuais e possuem o condão de produzir resultados dentro do processo, juridicamente protegidos ou não proibidos (BRAGA, 2007, p. 312).

2 A preocupação com a definição de fato jurídico tem ocupado principalmente os civilistas, mas não se pode, de modo algum, restringir a problemática ao Direito Civil, eis que se está diante de conceito jurídico 
como negócios jurídicos materiais.

Se faz necessária, antes de qualquer outra análise, portanto, a delimitação do conceito, do objeto e da classificação dos negócios jurídicos processuais no ordenamento jurídico pátrio.

\subsection{Conceito de negócio jurídico processual}

Na Teoria Geral do Direito a definição de negócio jurídico se destina justamente à distinção entre os atos negociais e os atos jurídicos em sentido estrito, e abarca os casos em que a vontade humana pode criar, modificar ou extinguir direitos, pretensões, ações ou exceções ${ }^{3}$, decorrentes do autorregramento da vontade (MIRANDA, 1954, t. 3, p. 3). A vontade, portanto, é manifestada para compor o suporte fático de certa categoria jurídica, visando à obtenção de efeitos jurídicos que podem ser predeterminados pelo sistema ou pactuados livremente (MELLO, 1991, p. 130).

José Frederico Marques (1999, p. 286-287) classifica os atos processuais como (i) postulatórios; (ii) dispositivos; (iii) probatórios; e (iv) reais, sendo que os negócios jurídicos processuais, no seu

fundamental, atinente a outras áreas jurídicas, como, por exemplo, o Direito Tributário e o próprio Direito Processual Civil. No campo do Direito Tributário, por exemplo, Paulo de Barros Carvalho (2009, p. 265) afirma que "No degrau da hermenêutica jurídica, o grande desafio de quem pretende desvelar conteúdo, sentido e alcance das regras de direito radica na inafastável dicotomia entre a letra da lei e a natureza do fenômeno jurídico subjacente". Especificamente sobre o fato jurídico, esclarece o autor que "Tem-se como certo, nos dias de hoje, que o conhecimento científico do fenômeno social, seja ele qual for, advém da experiência, aparecendo sempre como uma síntese necessariamente a posteriori. Na constituição do fato jurídico, a análise relacional entre a linguagem social e a linguagem jurídica, redutora da primeira, sobrepõe-se a esse conhecimento sinzetético, obtendo como resultado um novo signo, individualizado no tempo e no espaço do direito e recebendo qualificação jurídica: eis o fato jurídico" (CARVALHO, 2009, p. 270). Assim, é possível afirmar que o campo adequado para o enfoque do conceito do fato jurídico é a Teoria Geral do Direito (NOGUEIRA, 2016, p. 29-30).

3 Sobre a conceituação dos negócios jurídicos processuais a partir da sua distinção dos atos jurídicos processuais em sentido estrito, José Miguel Garcia Medina (2017, p. 313-314) afirma que "O elemento volitivo é relevante para a configuração do ato jurídico lato sensu, mas enquanto no ato jurídico stricto sensu os efeitos do ato realizado pela parte encontram-se previamente definidos na lei, no negócio jurídico aqueles que o celebram podem dispor também sobre tais efeitos". 
entendimento, integram a categoria dos atos dispositivos. Esclarece o jurista, então, que nela estão compreendidas as declarações de vontade dirigidas à produção de efeito jurídico determinado que corresponde à intenção e vontade do agente. São, então, "declarações de vontade destinadas por uma ou por todas as partes ao órgão jurisdicional, com o objetivo de produzir, no processo, efeitos jurídicos processuais".

Moacyr Amaral Santos (2007, p. 291-292), de modo semelhante, divide os atos processuais em (i) postulatórios; (ii) dispositivos; (iii) instrutórios; e (iv) reais, sendo que os atos dispositivos se subdividem em (i) unilaterais; (ii) concordantes; e (iii) contratuais, e "[...] são geralmente chamados negócios processuais, pois que conforme eles as partes regulam o próprio comportamento em relação à tutela jurisdicional".

Os negócios jurídicos processuais, neste aspecto, podem definidos como fato jurídico voluntário em cujo suporte fático se configura ao sujeito o poder de escolher a categoria jurídica ou estabelecer certas situações jurídicas processuais, observados os limites previstos no próprio ordenamento jurídico (NOGUEIRA, 2016, p. 153).

Sintetizando conceitos contemporâneos de negócios jurídicos processuais $^{4}$ Lorena Miranda Santos Barreiros (2016, p. 140) afirma que estes podem ser definidos como fatos voluntários que sofreram a incidência de norma processual, cujo suporte fático atribui ao sujeito o poder de decidir quanto à prática ou não do ato e quanto à definição dos seus efeitos. Assim, o sujeito pode (i) selecionar uma categoria jurídica eficacial já definida previamente pelo sistema jurídico; ou (ii) estabelecer, dentro dos limites fixados no ordenamento jurídico, determinadas situações jurídicas processuais ou alteração do procedimento.

4 A autora se embasa, aqui, nos pensamentos de Pedro Henrique Pedrosa Nogueira, Fredie Didier Junior, Alexandre Freire e Paula Sarno Braga (BARREIROS, 2016, nota de rodapé n. 206). 
Paula Sarno Braga (2007, p. 312) afirma que "serão negócios jurídicos processuais quando existir um poder de determinação e regramento da categoria jurídica e de seus resultados (com limites variados)".

Fredie Didier Jr. (2016b, p. 380), de forma similar, entende que negócio processual é fato jurídico voluntário, em cujo suporte fático se reconhece ao sujeito o poder de regular, dentro dos limites fixados no próprio ordenamento jurídico, certas situações jurídicas processuais, ou alterar o procedimento.

Antonio do Passo Cabral (2016, p. 68), por sua vez, define as "convenções ou acordos processuais" como "[...] negócio jurídico plurilateral, pelo qual as partes, antes ou durante o processo e sem necessidade de intermediação de nenhum outro sujeito, determinam a criação, modificação e extinção de situações jurídicas processuais, ou alteram o procedimento".

No que toca à denominação dos negócios jurídicos processuais, importa pontuar, por derradeiro, que o autor, admitindo que no direito contemporâneo estas noções se aproximam, e que “[...] há hoje menor utilidade em diferenciar todos estes termos porque a nomenclatura raramente interfere nos efeitos de cada categoria", diferencia as terminologias "acordos", "convenções", "pactos", "cláusulas" e "contratos" para se referir aos negócios jurídicos processuais (CABRAL, 2016, p. 51-58).

Segundo sua análise, então, o conceito de contrato não é adequado para se referir à negociação processual porque está intimamente ligado à ideia patrimonialista e puramente obrigacional, afastada dos negócios jurídicos processuais em razão do ambiente publicista em que estes se inserem. A expressão avença não possui sentido técnico 
específico, a palavra pacto possui mais utilização no âmbito do direito internacional e a terminologia protocolo é típica de certos tipos de acordos processuais firmados entre os tribunais e associações de advogados ou auxiliares da justiça. A designação cláusula, ao seu turno, pode até contemplar negócios completos (como a cláusula de eleição de foro e a cláusula compromissória), mas muitas vezes consiste em apenas parte das tratativas e por isso não é a mais adequada. As expressões acordo ou convenção, por sua vez, dizem respeito a uma união de vontades quanto à finalidade do ato praticado, e se opõem ao conceito de contrato porque não há necessidade de que os objetivos sejam diversos ou contrapostos; é possível, assim, que as vontades sejam comuns ou convergentes. Estas terminologias - acordo ou convenção - são as mais adequadas, segundo seu entendimento, porque remetem tanto à disciplina do direito privado, como também a outros ramos do direito.

José Carlos Barbosa Moreira (1984, p. 1-2) também afirma que a expressão "convenções processuais" é mais adequada, por possuir cunho mais técnico e por estar em consonância à linguagem do Código, que já no CPC/1973 utilizava o termo convenção nos arts. 111, 181, 265, II, $333,454, \S 1 .{ }^{\circ}, 606$, I, 656, 792, 1.028, 1.031, I, e 1.113, §3. ${ }^{\circ}$.

Tendo em vista a ausência de univocidade terminológica doutrinária na utilização destes termos, tanto no que se refere à sua natureza como no que toca aos seus efeitos, todos foram e serão utilizados neste trabalho como sinônimos de negócios jurídicos processuais.

\subsection{0 art. 190 do CPC/2015 como cláusula geral de negociação}

Por "cláusula geral" deve-se entender a espécie de texto que contém comandos indeterminados e que não prevê a consequência jurídica 
de sua inobservância. Sua hipótese fática (antecedente) é composta por termos vagos e seu efeito jurídico (consequente) é indeterminado. É possível afirmar que a cláusula geral se diferencia do conceito jurídico indeterminado, espécie de texto normativo igualmente formada por comandos indeterminados, mas que contém a previsão da consequência jurídica de seu descumprimento (REDONDO, 2015, p. 273, nota de rodapé n. 13).

Segundo Judith Martins-Costa (1999, p. 58) "a cláusula geral constitui, portanto, uma disposição normativa que utiliza, no seu enunciado, uma linguagem de tessitura intencionalmente "aberta", "fluida" ou "vaga", caracterizando-se pela ampla extensão em seu campo semântico $[\ldots]^{\prime \prime}$.

Para Claudio Luiz Bueno de Godoy (2004, p. 105-108), de modo muito semelhante, a cláusula geral se define como uma disposição normativa que utiliza em seu enunciado, intencionalmente, uma linguagem de tessitura intencionalmente aberta, vaga e fluida, e não é mais do que "[...] um mecanismo, conferido ao juiz, para procura da norma de decisão do caso concreto, que se pode conter num princípio, este, porém, diversamente daquela, caracterizado, já como uma autônoma normativa."

Teresa Arruda Alvim Wambier (2008, p. 161) entende que ao lado dos princípios jurídicos e dos conceitos vagos ou indeterminados ${ }^{5}$, as cláusulas gerais cada vez mais integram os textos legais, e se apresentam como elementos característicos do direito contemporâneo, que tende a ser aberto e flexível. Tratam-se as cláusulas gerais, portanto, de expressões,

5 Para a autora, “Os conceitos vagos ou indeterminados são expressões linguísticas (signos) cujo referencial semântico não é tão nítido, carece de contornos claros. Esses conceitos não dizem respeito a objetos fácil, imediata e prontamente identificáveis no mundo dos fatos. A interpretação dos conceitos vagos vem adquirindo cada vez mais importância no mundo contemporâneo porque o uso destes conceitos consiste numa técnica legislativa marcadamente afeiçoada à realidade em que hoje vivemos, que se caracteriza justamente pela sua instabilidade, pela imensa velocidade com que acontecem os fatos, com que se transmitem informações, se alteram "verdades" sociais" (WAMBIER, 2008, p. 152). 
cujo significado também é vago, que se consubstanciam em "poros" que fazem com que o direito se comunique com a realidade social.

É perfeitamente possível, então, ler, interpretar e aplicar o art. 190, caput, do CPC/2015 a partir do conceito cláusula geral, tendo em vista que a sua redação prevê que "Versando o processo sobre direitos que admitam autocomposição, é lícito às partes plenamente capazes estipular mudanças no procedimento para ajustá-lo às especificidades da causa e convencionar sobre os seus ônus, poderes, faculdades e deveres processuais, antes ou durante o processo".

José Miguel Garcia Medina (2016, p. 337) afirma que atípicos ou inominados são os negócios jurídicos processuais cujo regime não possui previsão legal, e o art. 190 do CPC/2015 estabelece, textualmente, a possibilidade de as partes celebrarem acordo sobre procedimentos, ônus, poderes, faculdades e deveres processuais. Cuida-se, então, de autorização para que as partes firmem negócios processuais, ainda que "[...] não se encontrem disciplinados ou sequer referidos, com antecedência, na lei”.

Na mesma linha é o posicionamento de Bruno Garcia Redondo (2015, p. 273), que entende que o art. 190 do CPC/2015 consagrou verdadeira cláusula geral de atipicidade de negócios processuais ${ }^{6}$, na medida em que não existe prévia estipulação das adequações que podem ser implementadas no procedimento, assim como inexiste menção do objeto dos acordos em matéria processual, ou seja, quais direitos, ônus,

6 No mesmo sentido, CABRAL, Antonio do Passo. Convenções processuais. Salvador: Editora JusPodivm, 2016, p. 330; CUNHA, Leonardo Carneiro da. Negócios jurídicos processuais no processo civil brasileiro. In: CABRAL, Antonio do Passo; NOGUEIRA, Pedro Henrique (org.). Negócios Processuais. Salvador: Editora JusPodivm, 2015. p. 27-62, p. 56; BOMFIM, Daniela Santos. A legitimidade extraordinária de ordem negocial. In: CABRAL, Antonio do Passo; NOGUEIRA, Pedro Henrique (org.). Negócios Processuais. Salvador: Editora JusPodivm, 2015. p. 335-352, p. 343; e LIPIANO, Julia; SIQUEIRA, Marília. Negócios jurídicos processuais sobre a fase recursal. In: CABRAL, Antonio do Passo; NOGUEIRA, Pedro Henrique (org.). Negócios Processuais. Salvador: Editora JusPodivm, 2015. p. 445-479, p. 451. 
poderes e faculdades podem ser convencionados.

Fredie Didier Jr. (2016a, p. 295) afirma que o art. 190, caput, do $\mathrm{CPC} / 2015$, é uma cláusula geral da qual se extrai o subprincípio da atipicidade da negociação processual, que decorre do princípio do autorregramento da vontade, já examinado. Segundo seu posicionamento, embora o legislador tenha utilizado o verbo "convencionar", no caput, e o termo "convenção", no parágrafo único, é certo que se está diante de autorização para celebrar negócios jurídicos processuais, que se apresentam como gênero do qual as convenções processuais são espécie.

Nos mesmos trilhos, Pedro Henrique Pedrosa Nogueira (2016, p. 227) afirma que o art. 190 é resultado do uso da técnica legislativa da cláusula geral, caracterizada por contemplar disposições normativas que utilizam em sua linguagem comandos abertos e vagos, viabilizando a abertura do sistema? .

Daniel Amorim Assumpção Neves (2016, p. 303) também entende que o art. 190, caput, do CPC/2015 representa cláusula geral que, diferentemente do CPC revogado, permite, além das hipóteses específicas de negócio processual típico, a celebração de acordo entre as partes de forma geral, envolvendo tanto o procedimento como as suas situações processuais.

José Carlos Barbosa Moreira (1984, p. 2-3) já há muito tempo sustenta que "[...] predomina a tese da admissibilidade de convenções não autorizadas expressis verbis na lei", muito embora houvesse o entendimento de que no processo (ramo do direito público) a autonomia da vontade não possui atuação tão ampla como no direito privado.

7 Sobre o tema, Rosa Maria de Andrade Nery (2015, p. 3-4): “Cria-se no processo um ambiente propício à proporcionalidade das pretensões deduzidas em juízo, que abre espaço para a compreensão do processo como um sistema semiaberto de normas, com cláusulas gerais, conceitos legais indeterminados e conceitos determinados pela função, com todas as suas implicações estruturais e funcionais". 
Assim, para o autor, por exemplo, nada impediria que autor e réu se comprometessem a não indicar assistentes técnicos, de modo que a diligência seria realizada exclusivamente pelo perito (MOREIRA, 1984, p. 3).

Antonio do Passo Cabral (2016, p. 148-150), em sua obra, traz interessante reflexão sobre as vantagens e as desvantagens de o art. 190, caput, do CPC/2015 se apresentar como cláusula geral de negociação processual. Como vantagens, tem-se (i) o encerramento, no direito brasileiro, do debate acerca da possibilidade de celebração de negócios processuais ${ }^{8}$; (ii) a dissipação da ideia de que a convencionalidade das partes se limitava aos negócios processuais típicos; e (iii) a estimulação de uma releitura do papel desempenhado pelas partes no processo, fornecendo limites mais amplos de interpretação à doutrina e à jurisprudência, que poderão construir uma tradição pátria sobre os negócios processuais. Como desvantagens, o autor menciona (i) a possibilidade de o sistema se tornar mais difícil de ser aplicado, pela vagueza textual e pela amplitude de interpretação; (ii) a redução da previsibilidade do sistema, atuando em desfavor da segurança jurídica; (iii) a ausência de previsão legal específica sobre diversos aspectos dos negócios jurídicos processuais, tais como objeto, critérios de validade, sujeitos do acordo, etc.

Estas críticas e desvantagens, entretanto, poderiam ser atribuídas a qualquer cláusula geral contida no ordenamento jurídico pátrio (como a cláusula geral da boa-fé objetiva, por exemplo), na medida em que não estão direcionadas ao art. 190 especificamente, mas sim à escolha

8 Neste sentido também o entendimento de Pedro Henrique Pedrosa Nogueira (2016, p. 227-228), que afirma que "Do ponto de vista da Ciência do Processo, pelas possibilidades de arranjos que o art. 190 do CPC/2015 permite acomodar, restará infrutífera a recusa doutrinária ao conceito de negócio jurídico processual, pois, mesmo para que os que trabalham com concepções voluntaristas de negócio jurídico, será possível identificar atos processuais em que as partes escolham os respectivos efeitos". 
legislativa de abertura sistemática da norma.

Vê-se, assim, que a leitura do art. 190 do CPC/2015 como cláusula geral de negociação processual significa dizer que o legislador de fato prestigiou o que se deve compreender por princípio do respeito ao autorregramento da vontade, deixando a cargo das partes não apenas o conteúdo do negócio, que é consideravelmente amplo, mas também a previsão sobre as consequências jurídicas das convenções processuais.

Cuidam-se as cláusulas gerais, indubitavelmente, como dito, de tendência no direito contemporâneo, assim como se verifica, no campo do Direito Privado, com a função social da propriedade, função social do contrato e a própria boa-fé objetiva? .

\subsection{Objeto dos Negócios Jurídicos Processuais}

No início desta seção cuidou-se de definir o negócio jurídico processual de acordo com o entendimento da mais autorizada doutrina, mas se faz necessário destacar, especificamente, o que qualifica o negócio jurídico como processual.

Tem-se, então, que para que receba a designação de "processual" o negócio jurídico deve referir-se a um processo, atual ou futuro, ao qual se direcionam seus efeitos ${ }^{10}$ (BARREIROS, 2016, p. 215). Tratase, então, de elemento completante ${ }^{11}$ do núcleo; sem ele, pode até haver

9 Neste sentido, WAMBIER, Teresa Arruda Alvim. Recurso especial, recurso extraordinário e ação rescisória. 2. ed. reformulada e atualizada da obra. São Paulo: Editora Revista dos Tribunais, 2008, p. 164-170).

10 Neste sentido, também, Pedro Henrique Pedrosa Nogueira (2016, p. 181): "O núcleo do suporte fático do negócio jurídico processual também se preenche com a referibilidade ao procedimento. O negócio jurídico será qualificado como processual quando se relacionar a um procedimento existente, ainda quando não integre a cadeia típica que o componha".

11 Sobre os elementos nucleares do suporte fático, Marcos Bernardes de Mello (2012,p. 85) explica que há o cerne e há os elementos completantes. Confira-se: "Geralmente, o suporte fático é complexo, sendo raras as espécies em que apenas um fato o compõe. No estudo dos suportes fáticos complexos, em especial dos negócios jurídicos, é preciso ter em vista que há fatos que, por serem considerados pela 
negócio jurídico de direito material (v.g. cláusula compromissória), mas lhe faltará a processualidade (NOGUEIRA, 2016, p. 181).

De mais a mais, da leitura do art. 190, caput, do CPC/2015 se extrai que as partes podem celebrar duas modalidades de acordos processuais: (i) aqueles que versam sobre o procedimento; e (ii) aqueles que dizem respeito aos seus ônus, poderes, faculdades e deveres processuais $^{12}$.

Tem-se, então, que o negócio jurídico processual atípico (celebrado, portanto, a partir da cláusula geral inserta no caput do art. 190), possui por objeto as situações jurídicas processuais (ônus, faculdades, deveres e poderes processuais) e também o ato processual (DIDIER JR., 2016a, p. 296).

Especificamente sobre o objeto dos negócios processuais Fredie Didier Jr. (2016b, p. 391-394) assenta oito premissas que devem ser observadas: (i) que, na dúvida, deve admitir-se o negócio processual; (ii) que a negociação atípica somente pode se realizar em causas que admitam autocomposição ${ }^{13}$; (iii) que o que se aplica à licitude do objeto do negócio jurídico privado também se aplica ao negócio jurídico processual; (iv)

\footnotetext{
norma jurídica essenciais à sua incidência e consequente criação do fato jurídico, constituem-se nos elementos nucleares do suporte fático ou, simplesmente, no seu núcleo. Dentre esses há sempre um fato que determina a configuração final do suporte fático e fixa, no tempo, a sua concreção. Às vezes esse fato não está, expressamente, mencionado, mas, por constituir o dado fático fundamental do fato jurídico, a sua presença é pressuposta em todas as normas que integram a respectiva instituição jurídica. Esse fato configura o cerne do suporte fático. Além do cerne, há outros fatos que completam o núcleo do suporte fático e, por isso, são denominados elementos completantes do núcleo".

12 Há, no entanto, acordos processuais que possuem como objeto procedimento e "posições processuais das partes". Neste sentido: "Exemplo interessante de negócio processual que, a um só tempo, envolve procedimento e disposição sobre posições processuais das partes, seria convenção pré-processual no sentido de que, em caso de execução, a penhora recairá sobre determinado bem imóvel (ainda que não se convencione hipoteca), e que o bem será alienado, em determinado prazo, por um entre dois ou três corretores de imóveis indicados no contrato, por no mínimo $50 \%$ da avaliação que dois desses corretores realizem. Uma solução como essa tenderia a agilizar a execução, movida por qualquer das partes" (MEDINA, 2017, p. 319).

13 Há que se ponderar que direito que admita autocomposição não é o mesmo que direito indisponível, na medida em que há direitos indisponíveis que admitam autocomposição, como os coletivos e o direito de alimentos (DIDIER JR., 2016b, p. 392).
} 
que sempre que regular expressamente um negócio processual, a lei determinará os contornos do seu objeto ${ }^{14}$; (v) que sempre que a matéria for de reserva legal, a negociação processual em torno dela é lícita ${ }^{15}$; (vi) que não se admite negócio processual que tenha por objeto afastar regra processual que sirva à proteção de direito indisponível; trata-se de negócio com objeto ilícito, porque dispõe sobre o afastamento de alguma regra processual cogente; (vii) que é possível inserir negócio processual em contrato de adesão, mas ele não pode ser abusivo; e (viii) no negócio processual atípico as partes podem definir outros deveres e sanções para o caso de seu descumprimento, distintos do rol legal de deveres e sanções processuais.

É bastante tênue a linha que distingue as normas processuais das procedimentais, mas a distinção existe tanto na Constituição Federal, nos já mencionados artigos 22, I, e 24, XI, e também no próprio art. 190, caput, do CPC/2015.

Como relembra Pedro Henrique Pedrosa Nogueira (2016, p. 228), a possibilidade de celebração de convenções processuais sobre procedimento, no Brasil, não é nova. Tanto que, como já mencionado, José Roberto dos Santos Bedaque (2006, p. 63) há muito tempo afirma que a flexibilização procedimental atende a ideia de processo justo alicerçada na Constituição Federal, desde que observado o princípio contraditório e desde que não subsista prejuízo às partes.

É possível afirmar que os negócios jurídicos processuais sobre procedimento não tocam a posição jurídica das partes, mas apenas aspectos formais atinentes ao rito do processo.

$14 \quad$ Neste sentido, o autor afirma que "Acordo sobre competência, por exemplo, é expressamente regulado (art. 63 do CPC) e o seu objeto, claramente definido: somente a competência relativa pode ser negociada" (DIDIER JR., 2016b, p. 393).

15 É o caso, por exemplo, dos recursos, que observam a regra da taxatividade: somente há os recursos previstos em lei, em rol taxativo (art. 994 do CPC) (DIDIER JR., 2016b, p. 393). 
Assim, a cláusula geral de negociação processual autoriza que as partes escolham o procedimento a ser seguido. Podem elas, ainda, construírem um novo rito, suprimindo atos processuais, invertendo a ordem de sua realização, alterando a sua forma ou o prazo para a sua prática, dentre outras possibilidades. Estes acordos dão azo, em regra, à flexibilização e modificação de regras preestabelecidas para o desenvolvimento processual (BARREIROS, 2016, p. 216).

Nada obstante a autorização para que as partes convencionem sobre procedimento, o caput do art. 190 do CPC/2015 autoriza também a celebração de negócios jurídicos processuais que tenham por objeto ônus, poderes, faculdades e deveres processuais, ou seja, que modifiquem, criem ou extingam situações jurídicas processuais (CABRAL, 2016, p. 290).

É importante, então, definir o que deve ser compreendido por (i) ônus; (ii) poderes; (iii) faculdades; e (iv) deveres processuais.

Cândido Rangel Dinamarco e Bruno Vasconcelos Carrilho Lopes (2017, p. 166) entendem que as partes possuem, em princípio, liberdade de agir no processo segundo suas próprias vontades e escolhas. Essa liberdade para o exercício das faculdades processuais ${ }^{16}$ encontra limite na esfera de direitos de outra pessoa, razão pela qual existem, no processo, normas impostas especificamente para limitar a sua extensão. Em regra, o não exercício de uma faculdade não impõe ao sujeito

16 Segundo Murilo Teixeira Avelino (2015, p. 5): “As faculdades representam o agere licere, ou seja, a possibilidade de atuação em face de uma norma permissiva. Quando esta possibilidade de atuação lícita faz referência a um ato processual, diz-se estar diante de uma faculdade processual. A faculdade é uma posição jurídica ativa que se exaure na esfera jurídica do próprio agente, não decorrendo daí uma necessária situação de vantagem ou desvantagem para o sujeito (o que a diferencia do ônus). Em nosso entender, aponte-se, a permissão para atuação é necessária a qualquer das demais situações jurídicas elencadas no art. 190 do NCPC. Poder-se-ia dizer, até, que ônus e poderes envolvem uma carga de facultatividade, no sentido de atuação, nestes casos, também não ser cogente, mas facultativa. Contudo, ônus e poderes não se confundem com "simples" faculdades, pois carregam consigo outros caracteres que os individualizam, conforme o que já se disse sobre os ônus e o que se diz, adiante, sobre os poderes". 
qualquer sanção, ainda que subsistam as consequências jurídicas desta conduta. É o caso, por exemplo, da decadência quanto ao não exercício de um direito potestativo, ou da preclusão, que consiste na perda da faculdade de praticar um ato processual (MEDINA, 2017, p. 312).

A expressão "poderes”, mencionada no dispositivo em análise, deve ser compreendida da forma mais ampla possível, abarcando direitos subjetivos e potestativos e poderes propriamente ditos (DIDIER JR., 2016b, p. 385).

O ônus, ao seu turno, consiste no encargo de assumir conduta comissiva ou omissiva como condição para obter vantagem ou para não suportar desvantagem. Difere do cumprimento das obrigações e dos deveres, que se realizam em benefício de outro sujeito, porque a observância dos ônus traz um benefício àquele que os cumpre, sempre em seu próprio interesse. É por este motivo que o cumprimento do ônus não pode ser exigido da parte e seu descumprimento não implica em ilícito, na medida em que a ninguém prejudica, a não ser ao próprio sujeito que não o cumpre (DINAMARCO; LOPES, 2017, p. 167).

José Frederico Marques (1999, p. 263-265) afirma, nesta esteira, que nos ônus processuais deixa a lei à livre vontade da parte onerada $\mathrm{o}$ cumprimento do imperativo jurídico ou a consequência danosa do seu descumprimento, e se constituem como estímulos para as partes, porque faltando a atuação do sujeito processual, que é o conteúdo do ônus, advém-lhe consequência prejudicial, ou pelo menos o risco de sofre-la.

Os deveres ${ }^{17}$, por outro lado, se apresentam como imperativos

17 Cândido Rangel Dinamarco e Bruno Vasconcelos Carrilho Lopes (2017,p. 168) afirmam, sobre os deveres processuais, que: "Os poucos deveres processuais impostos às partes são instituídos para a defesa do interesse público no correto e eficiente exercício da jurisdição. Essa é a justificativa para a reação da ordem jurídica, com a imposição de diversas formas de sanção. O mais amplo e expressivo dos deveres das partes é o de lealdade, com a expressa exigência de que as partes devem "comportar-se de acordo com a boa-fé" (art. 5..$^{\circ}$ e a repressão à litigância de má-fé e aos atos atentatórios à dignidade da Justiça, além do dever de cooperação, imposto a todos os sujeitos processuais (art. 6. ${ }^{\circ}$ )" (DINAMARCO; LOPES, 
do interesse alheio, e isso porque não os cumprir significa prejudicar um terceiro e não a si próprio (como ocorre com os ônus). É o caso da parte que, mentindo em juízo, está descumprindo o dever de lealdade processual, e o caso da testemunha que, não comparecendo para depor, descumpre o dever de comparecer (DINAMARCO; LOPES, 2017, p. 167).

Teresa Arruda Alvim Wambier, Maria Conceição, Leonardo Ribeiro e Rogério de Mello entendem que ônus, faculdades e poderes consistem em temas que preponderantemente atinem à esfera jurídica das partes. Assim, se o litigante entender conveniente dispor sobre um ônus que lhe caiba, ou sobre um poder ou uma faculdade, estará atuando em sua esfera privada. Já quanto aos deveres processuais, há evidente preponderância do caráter público, de modo que eventuais convenções sobre deveres poderão ser reputadas inválidas, por ser-lhe ilícito o objeto ${ }^{18}$ (WAMBIER et al., 2015, p. 356).

Antonio do Passo Cabral (2016, p. 293), no entanto, entende que a conclusão de que não são possíveis convenções processuais que deliberem sobre deveres representa um exagero. Isso porque, segundo o autor, o acordo das partes pode criar novar obrigações processuais para além dos deveres legalmente previstos, e podem, ainda, reforçar os deveres previstos na legislação, ampliando, por exemplo, as sanções

2017, p. 168).

18 Ainda sobre a (im)possibilidade de convenção, pelas partes, sobre seus deveres processuais, Teresa Arruda Alvim Wambier, Maria Conceição, Leonardo Ribeiro e Rogério de Mello prosseguem afirmando que: "O negócio jurídico processual, ao contrário dos negócios jurídicos materiais, reserva para si uma característica que lhe deve nortear a existência e a interpretação de suas disposições: tem por objeto uma relação de intenso color público (a própria relação processual é de direito público), e esta característica lhe é inata, o que exige sua compatibilização com normas processuais de caráter cogente, imperativo. Não se pode, é nossa convicção, dispor em negócio jurídico processual que uma decisão poderá não ser fundamentada, ou que não vigora o dever de cumprir as decisões judiciais. Admiti-lo seria algo incompatível à admissão do objeto ilícito na celebração do negócio jurídico processual" (WAMBIER et al., 2015, p. 356). 
para a prática de conduta indesejada ${ }^{19}$.

\subsection{Classificação dos negócios jurídicos processuais}

Quanto aos critérios de classificação dos negócios jurídicos processuais, adota-se, por uma questão de coerência às premissas conceituais já estabelecidas, a proposta de Fredie Didier Jr. (2016b, p. 381-383), que assim os divide: (i) negócios relativos ao objeto litigioso (como o reconhecimento da procedência do pedido) e negócios que possuem por objeto o próprio processo (como o acordo para suspensão do procedimento); (ii) negócios unilaterais (que se perfazem pela manifestação de apenas uma vontade, como a desistência e a renúncia; negócios bilaterais (que se perfazem pela manifestação de duas vontades) ${ }^{20}{ }^{21}$; e negócios plurilaterais (que se perfazem pela vontade de mais de dois sujeitos, como a sucessão processual voluntária ou os negócios que contam com a participação do juiz); (iii) negócios expressos (como o foro de eleição) e negócios tácitos (como o consentimento tácito do cônjuge para a propositura de ação real imobiliária); (iv) negócios jurídicos processuais que precisam de homologação judicial (como a desistência) e negócios que dispensam esta chancela (como o negócio tácito sobre a modificação de competência relativa ou a desistência do

19 Sobre o assunto, acrescenta o autor que "[...] é possível que haja acordos processuais sobre os deveres. Claro que o negócio jurídico não pode afastar deveres processuais legalmente estabelecidos, tais como o dever de lealdade, boa-fé ou o dever de veracidade, porque estabelecidos em nome da retidão do uso dos instrumentos processuais pelos sujeitos do processo. Por exemplo, convenções que autorizem a testemunha a mentir, ou que permitam a interposição de recurso protelatório, seriam inválidas" (CABRAL, 2016, p. 293).

20 Os negócios jurídicos processuais bilaterais, ainda, se dividem em (i) contratos, quando as vontades dizem respeito a interesses contrapostos; e (ii) acordos ou convenções, quando as vontades se unem para um interesse comum (DIDIER JR., 2016b, p. 382).

21 Segundo Rosa Maria de Andrade Nery (2015, p. 3), os negócios jurídicos unilaterais não são contratos, mas também expressam a força normativa da autonomia privada, " [...] porque neles se manifesta vontade dirigida para a consecução de fins que a parte delineia quais sejam". 
recurso) ${ }^{22}$; e, finalmente (v) negócios jurídicos processuais típicos e negócios jurídicos processuais atípicos.

Sobre os negócios jurídicos processuais típicos, importante destacar que José Miguel Garcia Medina (2017, p. 314) aponta como exemplos a convenção das partes sobre a suspensão do processo (art. 313 , II, do CPC/2015) ou sobre o ônus da prova (art. 373, §3. ${ }^{\circ}$, do $\mathrm{CPC} / 2015)$, "hipóteses em que prepondera o aspecto processual no objeto do negócio". Explica o autor, ainda, que parte da doutrina admite que a transação judicial (art. 487, III, b, do CPC/2015) é negócio jurídico processual, e traz exemplo muitíssimo interessante relativo à arrematação (alienação judicial na execução). Afirma, assim, que esta figura “[...] também ostenta, segundo pensamos, evidente natureza de negócio jurídico processual (cf. art. 903 do CPC/2015)".

Para o autor, há, também, outros exemplos resgatados da doutrina, como a convenção de arbitragem, a cláusula de eleição de foro, a desistência da ação, o reconhecimento jurídico do pedido, os acordos para abreviar ou ampliar prazos dilatórios e os pactos para não indicar assistente técnico, além daqueles que surgiram em razão das recentes reformas processuais, como (i) o plano de recuperação judicial; (ii) a alienação por iniciativa particular, na execução; (iii) os acordos sobre cronograma de cumprimento voluntário da sentença; (iv) a cláusula de mediação; e (v) a cláusula de conciliação (MEDINA, 2017, p. 315).

Os negócios processuais atípicos estão lastreados na cláusula geral de negociação sobre o processo (art. 190 do CPC) e no princípio

22 Segundo o entendimento do autor, seguido neste trabalho, por força do art. 200 do CPC a regra é a dispensa da necessidade de homologação judicial do negócio processual. Assim, "Negócios que tenham por objeto as situações jurídicas processuais dispensam, invariavelmente, a homologação judicial. Negócios processuais que tenham por objeto mudanças no procedimento podem sujeitar-se a homologação, embora nem sempre isso ocorra; é o que acontece, por exemplo, com a desistência (art. 200, par. ún., CPC) e a organização consensual do processo (art. 357, §2², CPC)" (DIDIER JR., 2016, p. 383). 
do respeito ao autorregramento processual (DIDIER JR., 2016b, p. 381), e serão tratados na próxima seção deste trabalho.

\section{FUNDAMENTOS PRINCIPIOLÓGICOS DOS NEGÓCIOS JURÍDICOS PROCESSUAIS}

Definir o que é princípio é tarefa extremamente difícil.

Sobre o tema, Nelson Nery Junior (2010, p. 34-35), em conhecida obra, depois de analisar os princípios à luz das obras de Robert Alexy, Ronald Dworkin, Lenio Luiz Streck, Canotilho e Josef Esser, conclui que os conceitos de norma, princípio, regra, direito e garantia não são uniformes na doutrina. $\mathrm{O}$ autor menciona, ainda, que "Talvez o pecado mais sério da doutrina hodierna seja o de tratar o tema mediante sincretismo, vale dizer, misturando-se as teorias que se utilizam de critérios e parâmetros distintos uns dos outros", e assume que até o momento não adotou nenhuma das correntes existentes, “[...] porquanto todas têm méritos e falhas, vantagens e desvantagens, coerências e incoerências".

José Miguel Garcia Medina (2013, online) também externou sua preocupação ${ }^{23}$ sobre a imprecisão da utilização do termo princípio para se referir, por exemplo, à dignidade da pessoa humana (art. 1. ${ }^{\circ}, \mathrm{III}$, da $\mathrm{CF}$ ), à função social da empresa, à premissa da nulla executio sine titulo, ao contraditório, à boa-fé objetiva e ao próprio dever de cooperação (que se analisará, adiante). Para o autor, embora frequentemente

23 Neste sentido, o autor menciona que "Minha maior preocupação está na prática, que vem se tornando bastante difundida, consistente em atribuir a algo a natureza de princípio para ponderá-lo com outro (?) princípio. Segundo esse modo de proceder, bastaria, no início de uma argumentação, chamar, v.g., preclusão de princípio, e, pronto!, isso autorizaria a "ponderação" do "princípio da preclusão" com outros "princípios"... Essa é uma atitude perigosa, pois pode ser usada como estratégia para se decidir contrariamente ao Direito" (MEDINA, 2013, online). 
recebam a designação de princípio, estes fenômenos não pertencem, necessariamente, a uma mesma categoria jurídica, e muitas vezes sequer deveriam ser chamados de princípio.

O fato é que se trata de assunto espinhoso e, embora muitíssimo interessante, a definição precisa do que vem a ser um princípio jurídico pouca relação guardaria com o foco deste estudo, razão pela qual passarse-á ao exame do princípio do respeito ao autorregramento da vontade e do princípio da cooperação partindo da ideia de que princípios são "[...] mandados de otimização, que são caracterizados por poderem ser satisfeitos em graus variados e pelo fato de que a medida devida de sua satisfação não depende somente das possibilidades fáticas, mas também das possibilidades jurídicas" (ALEXY, 2008, p. 90).

Convém pontuar, aliás, que estes dois princípios foram destacados para análise em razão da sua extrema importância ao que se deve compreender como fundamento dos negócios jurídicos processuais, mas também poder-se-ia mencionar aqui o princípio da liberdade ${ }^{24}-^{25}$ (do qual, aliás, decorre o princípio do respeito ao autorregramento da vontade,

Lorena Miranda Santos Barreiros (2016, p. 185), ao elencar os fundamentos da cláusula de atipicidade da negociação processual, relembra o princípio da liberdade, também compreendido como direito fundamental e mencionado já no preâmbulo da Constituição Federal de 1988 como valor social supremo. Para a autora, "Vista a liberdade em seus aspectos negativo (direito à não interferência na esfera pessoal do indivíduo) e positivo (autodeterminação, orientação da vontade dirigida a certa finalidade) e partindo-se da premissa de que o valor liberdade é dinâmico, ganhando contornos variados ao longo do tempo, pode-se extrair do princípio de liberdade (que veicula o valor supramencionado) o subprincípio do respeito ao autorregramento da vontade, que mais de perto e já na esfera infraconstitucional confere lastro à cláusula de aticipidade da negociação processual estudada" (BARREIROS, 2016, p. 186).

25 Sobre o princípio da liberdade convém fazer aqui uma pequena digressão ao que se pode compreender como liberdade negativa. César Augusto Ramos (2007, p. 302), ao explicar o liberalismo clássico, esclarece que um dos seus corolários reside na ideia de que "os indivíduos somente serão livres se eles forem sujeitos das suas escolhas e das suas decisões, definidas e decididas de modo a não sofrer a interferência arbitrária de outrem". Este é o conceito de liberdade negativa, isto é, "o indivíduo é livre apenas na ausência (negação de impedimentos) de ações de terceiros que podem criar obstáculos indevidos à livre atividade dos sujeitos". Assim, parece razoável concluir que a possibilidade de as partes convencionarem sobre procedimento de forma atípica se adequa às noções de liberdade negativa, tendo em vista (i) que o juiz não necessariamente é parte do negócio jurídico processual atípico; e (ii) que os negócios jurídicos processuais produzem efeitos imediatamente e independentemente de chancela judicial (art. 200 do CPC/2015), de modo que as partes, ao escolherem, por exemplo, que naquela lide específica não será produzida a prova pericial, estão exercendo sua liberdade sem interferência ou impedimento.

Revista do Direito Público, Londrina, v.12, n.3, p.242-278, dez.2017| DOI: 10.5433/1980-511X.2017v12n3p242 
que será analisado adiante) e o princípio dispositivo ${ }^{26}$, que, embora em menor grau, também guardam relação com os acordos processuais.

\subsection{Princípio do Respeito ao autorregramento da vontade no processo}

É também no princípio do autorregramento da vontade que se distinguem os negócios jurídicos e os atos jurídicos em sentido estrito (NOGUEIRA, 2016, p. 136).

Pontes de Miranda (1954, t. 3, p. 56) afirma que o que caracteriza o autorregramento da vontade é o poder de, com ele, compor o suporte fático dos atos jurídicos com o elemento nuclear da vontade, não importa em que ramo do direito. Alerta, ainda, que não é possível confundi-lo com a "autonomia da vontade": "[...] porque, com isso, se elidiria, desde a base, qualquer auto-regramento da vontade, em direito público, - o que seria falsíssimo (MIRANDA, 1954, t. 3, p. 56).

Relembre-se que a teoria dos negócios jurídicos foi fundamentalmente desenvolvida tendo por objeto relações jurídicas de direito privado, que é onde se manifesta a gigantesca maioria dos negócios jurídicos, eis que, guiados pela autonomia privada ${ }^{27}$, os participantes do

26 Acerca do princípio dispositivo, Antonio do Passo Cabral (2016, p. 138) afirma que: "A máxima dispositiva, em suma, indica o poder dos litigantes: de iniciar o processo, provocando a jurisdição inerte; de conformar o objeto do processo (apresentando a pretensão em forma de pedido, limitando assim a sentença pela aplicação da regra da adstrição ou congruência entre libelo e decisão: ne eat iudex ultra petita partium); e de dispor in totum do conteúdo da situação jurídica litigiosa (veja-se a transação, p.ex.). O princípio dispositivo tem base constitucional, deriva do direito de liberdade e das garantias processuais referentes ao acesso à Justiça, à inafastabilidade do controle jurisdicional e aos direitos de ação e defesa. Estes direitos fundamentais atribuem aos litigantes não só iniciativa, no sentido de propor a demanda pelo exercício da ação, mas também uma ampla margem de liberdade de atuação processual em razão de sua vontade".

27 Cabe aqui uma pequena ressalva quanto à distinção entre os conceitos de autonomia da vontade e autonomia privada. Sobre o tema, Judith Martins Costa afirma que: "A expressão 'autonomia da vontade' não deve ser confundida com o conceito de 'autonomia privada', e nem com a sua expressão no campo dos negócios jurídicos, qual seja, a 'autonomia negocial'. A 'autonomia da vontade' designa uma construção ideológica, datada dos finais do século passado [século XIX] por alguns juristas para opor-se aos excessos do liberalismo econômico. Modernamente designa-se como 'autonomia privada' (dita, no campo dos negócios, 'autonomia negocial') seja um fato objetivo, vale dizer, o poder, reconhecido pelo 
negócio jurídico criam, modificam ou extinguem relações de direitos (HATOUM; BELLINETTI, 2016, p. 54). Entretanto, conquanto se manifeste com muito maior amplitude do âmbito do direito privado, que tem como uma de suas fundamentais características a autonomia das vontades, o negócio jurídico pode dar-se também no âmbito das relações jurídicas processuais (WAMBIER et al., 2015, p. 352).

$\mathrm{O}$ direito fundamental à liberdade (art. 5. ${ }^{\circ}$, caput, da CF) possui conteúdo complexo, e, enquanto princípio - o princípio da liberdade -, também atua no processo produzindo um subprincípio: o princípio do respeito ao autorregramento da vontade no processo, que, por sua vez, se apresenta como uma dimensão inafastável da dignidade da pessoa humana, e se define como um complexo de poderes que podem ser exercidos pelos sujeitos de direito, em níveis de amplitude variada, de acordo com o ordenamento jurídico (DIDIER JR., 2015, p. 20).

Nesta esteira, tendo em vista o caráter público do Direito Processual Civil, é certo que o princípio do respeito ao autorregramento da vontade não tem, na esfera processual, a mesma roupagem e amplitude verificada, por exemplo, na esfera do Direito Civil, eis que envolve o exercício de uma função pública, a jurisdição. Isso não impede, entretanto, que lhe seja dada a devida importância e destaque (DIDIER JR., 2015, p. 20).

No campo das convenções em matéria processual há, ainda, uma gradação de limites, que serão maiores nos negócios processuais que versem sobre o procedimento, se comparados com os limites impostos

ordenamento jurídico aos particulares, e nos limites traçados pela ordem jurídica, de autorregular os seus interesses, estabelecendo certos efeitos aos negócios que pactuam, seja a fonte de onde derivam certos direitos e obrigações (fonte negocial), seja as normas criadas pela autonomia privada, as quais têm um conteúdo próprio, determinado pelas normas estatais (normas heterônomas, legais ou jurisdicionais) que as limitam, subtraindo ao poder derivado autônomo certas matérias, certos grupos de relações, reservadas à regulação pelo Estado" (MARTINS-COSTA, 2002, p. 614-615). 
às convenções que possuem por objeto situações jurídicas processuais. Mas, em todos os casos, a regra é a liberdade e a exceção, o limite (BARREIROS, 2016, p. 189).

É possível verificar o exercício do autorregramento da vontade em quatro zonas da liberdade: (i) liberdade de negociação (zona das negociações preliminares, antes da consumação do negócio); (ii) liberdade de criação (possibilidade de criar novos modelos negociais atípicos que melhor sirvam aos interesses dos indivíduos); (iii) liberdade de estipulação (faculdade de estabelecer o conteúdo do negócio); e (iv) liberdade de vinculação (faculdade de celebrar ou não o negócio) (NOGUEIRA, 2016, p. 137).

É certo que os negócios jurídicos processuais se manifestam em observância às quatro zonas da liberdade (negociação, criação, estipulação e vinculação), mas é na liberdade de criação que melhor se apresentam, especialmente se levada em consideração a atipicidade das negociações celebradas com fulcro no art. 190 do CPC/2015.

Leonardo Carneiro da Cunha, em uma análise do princípio do autorregramento da vontade, esclarece que há, no CPC/2015, além do art. 190, diversos dispositivos que prestigiam a autonomia da vontade das partes. O novo Código trata, por exemplo, da autocomposição, regulando a mediação e a conciliação (arts. 165 a 175), inserindo a tentativa de autocomposição como ato anterior à defesa do réu (arts. 334 a 695) e permitindo, no acordo judicial, a inclusão de matéria estranha ao objeto litigioso do processo (art. 515, § 2. ${ }^{\circ}$ ). Há, segundo ele, aliás, um forte estímulo à autocomposição no $\mathrm{CPC} / 2015$, destacando-se os $\S \S 2 .^{\circ}$ e $3 .^{\circ}$ do seu art. 3. ${ }^{\circ}$ (CUNHA, 2015, p. 50).

Afirma o autor, assim, que o autorregramento da vontade no Novo Código é permitido, assegurado e respeitado, eis que o diploma 
foi estruturado de maneira a estimular a solução do conflito pela via que parecer mais adequada a cada caso, não erigindo a jurisdição como necessariamente a melhor opção para eliminar a disputa de interesses (CUNHA, 2015, 49-50).

Esta opinião é corroborada pelo entendimento de Fredie Didier Jr. (2015, p. 23), para quem o novo CPC consagra um sistema coerente e que reforça a existência de um princípio comum a diversas outras normas, o do autorregramento da vontade no processo civil.

Embora não esteja o princípio do respeito ao autorregramento da vontade previsto expressamente no $\mathrm{CPC} / 2015$, já era abarcado pelo $\mathrm{CPC} / 1973^{28}$ e deve ser inserido no rol de normas fundamentais do processo civil, porque implicitamente previsto no referido diploma (DIDIER JR., 2015, p. 19), e diversos são os exemplos, no CPC/2015, de sua manifestação: (i) quando o Código estimula a solução de conflitos por autocomposição (art. 165-175; arts. 334 e 695; art. 515, III; art. 725, VIII; art. 515, §2. ${ }^{\circ}$; e art. 190); (ii) quando estabelece que é a vontade da parte que delimita o objeto litigioso do processo (arts. 141 e 490) e do

$28 \quad$ Sobre eventuais entendimentos no sentido de que o autorregramento da vontade se apresenta como novidade trazida pelo CPC/2015, se revela pertinente a crítica de Jaldemiro Rodrigues de Ataíde Júnior: "É, no mínimo, questionável a asserção de que o CPC/2015 instituiu o princípio da autonomia ou do autorregramento da vontade no processo. Instituiu mesmo? No regime do CPC/1973, já não deve haver respeito à autonomia da vontade no processo? As características que se têm apontado para defender a criação, pelo CPC/2015, do princípio da autonomia ou do autorregramento da vontade no processo - tais como: o incentivo à autocomposição; a delimitação do objeto litigioso do processo pela vontade as partes; a previsão de um significativo número de negócios processuais típicos; a positivação do princípio da cooperação e a previsão de uma cláusula geral de negociação processual - já estão todas presentes, embora que com menor nitidez, no sistema processual do CPC/1973, iluminado pela $\mathrm{CF} / 1988$. Aliás, o art. 158 do $\mathrm{CPC} / 1973$ já estabelece que "Os atos das partes, consistentes em declarações unilaterais ou bilaterais de vontade, produzem imediatamente a constituição, a modificação ou a extinção de direitos processuais". Além disso, afigura-se uma contradição em termos falar-se em ato processual, sem se atribuir relevância à vontade, afinal, esta é o elemento nuclear do suporte fático dos atos jurídicos lato sensu, dentre os quais se encontram (i) o ato jurídico stricto sensu (incluso o ato proçessual) e (ii) o negócio jurídico (incluso o negócio jurídico processual) (ATAIDE JÚNIOR, 2015, p. 1-2). 
recurso (arts. 1.002-1.013); (iii) quando prevê um número significativo de negócios processuais típicos (art. 63; art. 65; art. 168; art. 191; art.

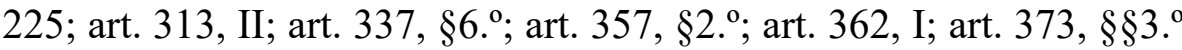
e 4. ${ }^{\circ}$; art. 471; art. 775; art. 998; art. 999; art. 1.000, dentre outros; (iv) consagra o princípio da cooperação (art. 6. ${ }^{\circ}$ do CPC/2015); (v) prestigia a arbitragem (Lei n. 9.307/1996); e (vi) prevê uma cláusula geral de negociação processual (art. 190 do CPC/2015) (DIDIER JR., 2015, p. 23-25).

\subsection{Princípio da Cooperação}

O art. 6. ${ }^{\circ}$ do $\mathrm{CPC} / 2015$ prevê que "Todos os sujeitos do processo devem cooperar entre si para que se obtenha, em tempo razoável, decisão de mérito justa e efetiva", inserindo, assim, o princípio da cooperação como uma das normas fundamentais do processo civil.

Este dispositivo exerce duas funções importantes no ordenamento jurídico-processual brasileiro: (i) estruturar o processo civil sob o modelo cooperativo; e (ii) firmar o funcionamento do sistema processual a partir do princípio da cooperação ${ }^{29}$. Dentre os fins almejados pelo princípio da cooperação se encontram o combate ao desperdício, a primazia das decisões de mérito em desfavor das processuais, a busca da verdade e o emprego de técnicas executivas adequadas à efetivação dos direitos (MITIDIERO, 2015, p. 48-49).

Assim, é possível afirmar que o princípio da cooperação decorre do próprio regime democrático, que exige a participação de todos aqueles

29 Elve Miguel Cenci (2014, p. 28), a este respeito, afirma que no mundo globalizado “[...] formado por sociedades complexas, não nascemos, crescemos e nos casamos na mesma aldeia. Mas a complexidade não elimina a possibilidade do entendimento. A palavra de ordem se chama colaboração. Sai a estratégia, a astúcia, e entra em cena a colaboração. Não por acaso o novo CPC incorporou a ideia como princípio". 
que possam ser atingidos pelo exercício da jurisdição, que, aliás, só assim poderá ser considerado legítimo. No âmbito do processo a cooperação é verificada com a participação das partes e terceiros que devem construir, juntamente com o juiz, a decisão (WAMBIER et al., 2015a, p. 70).

Neste sentido, inclusive, tem-se que a decisão judicial “[...] somente alcançará a esperada legitimidade democrática, e via de consequência, a almejada rapidez e justiça, se a cooperação for uma constante no iter processual" (WAMBIER et al., 2015a, p. 72).

A colaboração deve vigorar entre as partes, das partes para com o juiz do juiz para com as partes (MEDINA, 2016, p. 54-55) ${ }^{30}$, e ocorre através da prática dos atos processuais, que no que toca as partes realizase com o exercício dos direitos de ação, defesa e manifestação em geral, e no que toca o magistrado se efetiva através das ordens e decisões. A cooperação, como dever imposto aos sujeitos do processo, também pressupõe uma harmoniosa sintonia na prática de atos processuais, os quais devem ser realizados sempre sob o signo da boa-fé (WAMBIER et al., 2015a, p. 71).

Há inegável relação entre o princípio da cooperação e o autorregramento da vontade, na medida em que o modelo cooperativo estrutura o sistema de modo que este se torna mais receptivo aos negócios jurídicos processuais, prestigiando o respeito à atuação das partes no processo, aniquilando o dogma da irrelevância da vontade no processo e motivando o juiz à adoção de uma postura menos autoritária e mais comunicativa ${ }^{31}$. Por outro lado, o princípio da cooperação funciona

$30 \quad$ Neste sentido: "O princípio da cooperação não mais admite seja o processo visto como uma estrutura hierarquizada, onde as partes se submetam a um Estado-juiz superpoderoso ou, muito menos, um Estado ausente, expectador do embate livre entre as partes exercendo mero papel de mediador; hoje o Estado-juiz é membro do contraditório, somente se sobrelevando no momento de proferir a decisão, fruto de um diálogo democrático, ético e participativo na prestação da jurisdição" (AVELINO, 2015, p. 3).

31 O processo, neste contexto, deve ser compreendido como uma "comunidade de comunicação", desenvolvendo-se por um diálogo pelo qual se permite uma discussão a respeito de todos os aspectos de 
como limite objetivo à celebração dos negócios jurídicos processuais ${ }^{32}$, sendo vedada, por exemplo, convenção que afaste os deveres inerentes à colaboração (BARREIROS, 2016, p. 191-192).

Há também relação entre o princípio da cooperação, estatuído no art. 6. ${ }^{\circ}$ do $\mathrm{CPC} / 2015$, com outros que também são considerados normas fundamentais do processo civil, como o princípio do contraditório (art. 9..$^{\circ}$ do $\mathrm{CPC} / 2015$ ) e o princípio da duração razoável do processo (art. 4. ${ }^{\circ}$ do $\left.\mathrm{CPC} / 2015\right)$.

Com relação à norma do art. $4 .^{\circ}$ do $\mathrm{CPC} / 2015$, José Miguel Garcia Medina (2016, p. 56) entende que " $\mathrm{O}$ art. 6. ${ }^{\circ}$ do CPC/2015 reitera algo que, de certo modo, já consta do art. $4 .^{\circ}$ do CPC/2015, mas sob outra perspectiva. $\mathrm{O}$ art. $4 .^{\circ}$ do $\mathrm{CPC} / 2015$ reproduz, na lei processual, o princípio estampado no art. 5. ${ }^{\circ}$, LIIVIII da CF/1988, que assegura às partes a duração razoável do processo". E acrescenta que "O art. 6. do CPC/2015, por sua vez, refere-se ao dever de cooperação para que esse resultado seja alcançado. Os dois dispositivos legais referem-se, de todo modo, a um mesmo objetivo: a solução do mérito ${ }^{33}$ ".

Quanto à norma do art. 9..$^{\circ}$ do $\mathrm{CPC} / 2015$, Leonardo Carneiro da Cunha (2016, p. 42-43) afirma que "A participação propiciada pelo contraditório serve não apenas para que cada litigante possa influenciar a decisão, mas também para viabilizar a colaboração das partes com o exercício da atividade jurisdicional" e, mais à frente, conclui que "Em razão do contraditório, a atividade jurisdicional deve pautar-se num

fato e de direito considerados relevantes para a decisão da causa (SILVA, 2003, p. 578-579).

32 No mesmo sentido, Antonio do Passo Cabral (2016, p. 318): “[...] os poderes do juiz de condução do processo permitem controlar a observância dos deveres derivados da boa-fé e da cooperação, limitando o autorregramento da vontade no equilíbrio entre autonomia dos litigantes e os interesses públicos presentes no processo".

33

A premissa de que o princípio da cooperação visa à construção da decisão judicial com a participação das partes parece consenso na doutrina. Confira-se, a este respeito: "A decisão judicial não deve ser fruto de um trabalho exclusivo do juiz, mas resultado de uma atividade conjunta, em que há interações constantes entre diversos sujeitos que atuam no processo" (CUNHA, 2016, p. 42-43). 
esquema dialógico, de modo a exigir que o juiz exerça a jurisdição com o auxílio das partes".

Loïc Cadiet (2015, p. 103), nesta esteira, menciona que é necessário prestigiar o princípio da cooperação, que é característica do processo civil contemporâneo e se contrapõe ao modelo de processo acusatório e inquisitório. Afirma, ainda, que os acordos processuais revelam que o processo não é "obra" exclusiva do juiz ou das partes, e que, a exemplo do que ocorre no procedimento arbitral, o modelo de processo cooperativo é o que tende a ser desenvolvido.

É possível afirmar, assim que os negócios jurídicos processuais possuem fundamento no princípio da cooperação ${ }^{34}$, na medida em que, como visto, o ambiente cooperativo viabiliza que as vontades sejam convergentes ao ponto de tornar o processo e o procedimento mais adequado às especificidades da causa, que é o escopo das convenções processuais atípicas.

\section{CONCLUSÃo}

Como anunciado na introdução, esta pesquisa se propôs ao estudo do que se deve compreender como os fundamentos principiológicos dos negócios jurídicos processuais celebrados a partir da cláusula geral de negociação, o art. 190, caput, do CPC/2015.

A primeira, é que é plenamente possível estudar os negócios jurídicos processuais a partir da sua contextualização na Teoria dos Fatos Jurídicos Processuais, ou seja, enquanto espécie de ato jurídico processual lato sensu (ao lado do ato jurídico processual stricto sensu)

$34 \quad$ Neste sentido, também NERY JUNIOR, Nelson; NERY, Rosa Maria de Andrade. Comentários ao Código de Processo Civil. São Paulo: Revista dos Tribunais, 2015, p. 701. 
porque a vontade é núcleo do suporte fático e se dirige à produção de efeitos não necessariamente previstos na legislação.

A segunda, é que o estudo dos negócios jurídicos processuais exige a prévia análise dos seus aspectos mais relevantes, tais como seu conceito, objeto e classificação. Também se faz necessária a compreensão do art. 190, caput, enquanto cláusula geral de negociação, uma vez que o referido dispositivo se apresenta como um comando amplo e aberto, e que não possui a previsão das consequências de sua inobservância.

A terceira, então, refere-se à possibilidade de exame dos negócios jurídicos processuais como reflexo direto da observância ao princípio do autorregramento da vontade no processo e ao princípio da cooperação. No que toca especificamente ao princípio do respeito ao autorregramento da vontade no processo, tem-se que o CPC/2015 o prestigia em diversas situações, inclusive elevando o incentivo aos meios adequados de solução de conflitos como norma fundamental do processo civil (cf. art. 3. ${ }^{\circ}, \S 3 .^{\circ}$, do CPC/2015). Mesma sorte se dá ao princípio da cooperação, amplamente difundido e agora positivado, também inserido na nova legislação como norma fundamental do processo civil (cf. art. $6^{\circ}$ do CPC). A compreensão do instituto a partir destes dois princípios revela uma tendência que culmina nas noções de processo civil democrático, porquanto conta com a efetiva participação das partes para a construção do processo e também dos seus resultados.

E, por fim, a quarta, é que os negócios processuais se apresentam como uma importante ferramenta de acesso à justiça, aqui compreendido não apenas como o direito de ação ou o acesso da parte ao Poder Judiciário, mas o direito humano e fundamental de obtenção de uma prestação jurisdicional justa, eficaz e concedida em prazo razoável. E isso porque a possibilidade de celebração de negócios jurídicos processuais 
atípicos tende a ajustar o processo e o procedimento às especificidades da causa, proporcionando julgamentos que sejam mais adequados e que confiram às partes um maior grau de satisfação e conformidade com o resultado, porque dele participaram.

\section{REFERÊNCIAS}

ALEXY, Robert. Teoria dos direitos fundamentais. São Paulo: Malheiros, 2008.

ATAÍDE JUNIOR, Jaldemiro Rodrigues de. Negócios jurídicos materiais e processuais - existência, validade e eficácia - campo-invariável e campos-dependentes: sobre os limites nos negócios jurídicos processuais. Revista de Processo, São Paulo, v. 244, p. 393-423, jun. 2015.

AVELINO, Murilo Teixeira. A posição do magistrado em face dos negócios jurídicos processuais. Revista de Processo, São Paulo, v. 246, p. 219-238, ago. 2015. Disponível em $<$ http://migre.me/wGELA > Acesso em: 19 maio 2017.

BARREIROS, Lorena Miranda Santos. Convenções processuais e poder público. Salvador: Juspodivm, 2016.

. Efetividade do processo e técnica processual. São Paulo: Malheiros, 2006.

BOMFIM, Daniela Santos. A legitimidade extraordinária de ordem negocial. In: CABRAL, Antonio do Passo; NOGUEIRA, Pedro Henrique (org.). Negócios Processuais. Salvador: Juspodivm, 2015. p. 335-352.

BRAGA, Paula Sarno. Primeiras reflexões sobre uma Teoria do Fato Jurídico Processual: plano da existência. Revista de Processo, São Paulo, n. 148, p. 293-320, jun. 2007. 
CABRAL, Antonio do Passo. Convenções processuais. Salvador: Juspodivm, 2016.

CADIET, Loïc. La qualification juridique des accords processuels. In: CABRAL, Antonio do Passo; NOGUEIRA, Pedro Henrique (Org.). Negócios Processuais. Salvador: Juspodivm, 2015. p. 93-103.

CARVALHO, Paulo de Barros. Curso de Direito Tributário. 21. ed. São Paulo: Saraiva, 2009.

CENCI, Elve Miguel. Considerações jusfilosóficas acerca dos meios alternativos para a resolução de conflitos: uma perspectiva kantiana. In: MUNIZ, Tânia Lobo; ARAUJO JUNIOR, Miguel Etinger de (Org.). Estudos em direito negocial e os mecanismos contemporâneos de resolução de conflitos. Birigüi: Boreal Editora, 2014. p. 17-28.

CUNHA, Leonardo Carneiro da. Art. 6. ${ }^{\circ}$ In: STRECK, Lenio Luiz; NUNES, Dierle; CUNHA, Leonardo Carneiro da; (Org.). Comentários ao Código de Processo Civil. São Paulo: Editora Saraiva, 2016. p. 41-44.

. Negócios jurídicos processuais no processo civil brasileiro. In: CABRAL, Antonio do Passo; NOGUEIRA, Pedro Henrique (Org.). Negócios Processuais. Salvador: Juspodivm, 2015. p. 27-62.

DIDIER JR., Fredie; CUNHA, Leonardo Carneiro da. Curso de Direito Processual Civil. 8. ed. Salvador: Juspodivm, 2015. v. 3.

. Art. 190. In: STRECK, Lenio Luiz; NUNES, Dierle; CUNHA, Leonardo Carneiro da; (Org.). Comentários ao Código de Processo Civil. São Paulo: Saraiva, 2016. p. 293-303.

. Curso de direito processual civil: introdução ao direito processual civil, parte geral e processo de conhecimento. 18. ed. Salvador: Juspodivm, 2016. 
DINAMARCO, Cândido Rangel; LOPES, Bruno Vasconcelos Carrilho. Teoria geral do novo processo civil. 2. ed. São Paulo: Malheiros, 2017.

GODOY, Claudio Luiz Bueno de. Função social do contrato: os novos princípios contratuais. São Paulo: Saraiva, 2004.

HATOUM, Nida Saleh; BELLINETTI, Luiz Fernando. Aspectos relevantes dos negócios jurídicos processuais previstos no art. 190 do CPC/2015. Revista de Processo, São Paulo, n. 260, p. 49-71, out. 2016.

LIPIANI, Julia; SIQUEIRA, Marília. Negócios jurídicos processuais sobre a fase recursal. In: CABRAL, Antonio do Passo; NOGUEIRA, Pedro Henrique (Org.). Negócios Processuais. Salvador: Juspodivm, 2015. p. 445-479.

MARQUES, José Frederico. Instituições de Direito Processual Civil. Campinas: Millennium Editora Ltda., 1999. v. 2.

MARTINS-COSTA, Judith. A boa-fé no direito privado: sistema e tópica no processo obrigacional. São Paulo: Revista dos Tribunais, 1999.

. Mercado e solidariedade social entre cosmos e taxis: a boa-fé nas relações de consumo. São Paulo: Revista dos Tribunais, 2002.

MEDINA, José Miguel Garcia. Afinal de contas, o que é um princípio jurídico? Revista Consultor Jurídico, São Paulo, 26 ago 2013. Disponível em: < http://www.conjur.com.br/2013-ago-26/processoafinal-contas-principio-juridico $>$. Acesso em: 26 abr. 2017.

. Novo Código de Processo Civil comentado: com remissões e notas comparativas ao CPC/1973. 4. ed. São Paulo: Revista dos Tribunais, 2016. 
. Novo Código de Processo Civil comentado: com remissões e notas comparativas ao CPC/1973. 5. ed. São Paulo: Revista dos Tribunais, 2017.

MELLO, Marcos Bernardes de. Teoria do fato jurídico. 4. ed. São Paulo: Saraiva, 1991.

. Teoria do fato jurídico: plano da existência. São Paulo: Saraiva, 2012.

MITIDIERO, Daniel. A colaboração como norma fundamental do novo processo civil brasileiro. Revista do Advogado, São Paulo, n. 126, p. 47-52, maio 2015.

MIRANDA, Pontes de. Tratado de Direito Privado: Parte Geral. Rio de Janeiro: Borsoi, 1954. t. 3.

MOREIRA, José Carlos Barbosa. Convenção das partes sobre matéria processual. Revista de Processo, São Paulo, v. 33, p. 182-191, jan./mar. 1984. Disponível em: <http://migre.me/wGFlf > Acesso em: 19 maio 2017.

NERY, Rosa Maria de Andrade. Fatos Processuais: atos jurídicos processuais simples, negócio jurídico processual (unilateral e bilateral), transação. Revista de Direito Privado, São Paulo, v. 64, p. 261-274, out./dez. 2015. Disponível em: <http://migre.me/wGEIa > Acesso em: 19 maio 2017.

NERY JUNIOR, Nelson. Princípios do processo na Constituição Federal: processo civil, penal e administrativo. 10. ed. rev., ampl. e atual. com as novas súmulas do STF (simples e vinculantes) e com análise sobre a relativização da coisa julgada. São Paulo: Revista dos Tribunais, 2010. 
NEVES, Daniel Amorim Assumpção. Novo Código de Processo Civil Comentado. Salvador: Juspodivm, 2016.

NOGUEIRA, Pedro Henrique. Negócios jurídicos processuais. 2. ed. Salvador: Juspodivm, 2016.

RAMOS, César Augusto. A concepção republicana de liberdade como não-dominação. Crítica: Revista de Filosofia, Londrina, v. 12, n. 36, p. 301-336, out. 2007.

REDONDO, Bruno Garcia. Negócios processuais: necessidade de rompimento radical com o sistema do CPC/1973 para a adequada compreensão da inovação do CPC/2015. In: CABRAL, Antonio do Passo; NOGUEIRA, Pedro Henrique (Org.). Negócios Processuais. Salvador: Juspodivm, 2015. p. 269-278.

SANTOS, Moacyr Amaral. Primeiras linhas de direito processual civil. 25. ed. São Paulo: Saraiva, 2007. v. 1.

SILVA, Paula Costa e. Acto e processo. Coimbra: Coimbra, 2003.

THEODORO JUNIOR, Humberto. Curso de direito processual civil: teoria geral do direito processual civil, processo de conhecimento e procedimento comum. 58. ed. Rio de Janeiro: Forense, 2017. v. 1.

WAMBIER, Teresa Arruda Alvim. Recurso especial, recurso extraordinário e ação rescisória. 2. ed. São Paulo: Revista dos Tribunais, 2008.

et al. Breves comentários ao Novo Código de Processo Civil. São Paulo: Revista dos Tribunais, 2015.

Como citar: HATOUM, Nida Saleh. BELLINETTI, Luiz Fernando. Fundamentos principiológicos dos negócios jurídicos processuais previstos 
no art. 190 do CPC/2015. Revista do Direito Público, Londrina, v. 12, n. 3, p.242-278, dez. 2017. DOI: 10.5433/1980-511X2017v12n3p242. ISSN: $1980-511 X$.

Recebido em:

Aprovado em: 11/12/2017 